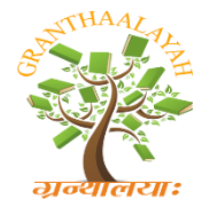

INTERNATIONAL JOURNAL OF RESEARCH GRANTHAALAYAH A knowledge Repository

Management

\title{
AN OVERVIEW ABOUT JIT (JUST-IN-TIME) - INVENTORY MANAGEMENT SYSTEM
}

\author{
Dr. C. Eugine Franco ${ }^{* 1}$, S. Rubha ${ }^{2}$ \\ ${ }^{* 1}$ Associate Professor of Commerce, St. Xavier's College (Autonomous), Tirunelveli, Tamil \\ Nadu, India \\ ${ }^{2}$ Assistant Professor of Commerce, Sadakathullah Appa college, (Autonomous), Tirunelveli, \\ Tamil Nadu, India
}

DOI: https://doi.org/10.29121/granthaalayah.v5.i4(SE).2017.1944

\begin{abstract}
A stock out is undesirable for manufacturers because it halts the production process. An inventory is the stock of ideal resources in a firm for future use. Manufacturing organizations typically have raw materials, components, sub-assemblies, tools and equipment's; semi-finished goods etc., the inventory of an item should not be neither too high nor too less. It should be optimal. The recent development in inventory management is JIT (Just-in-Time). JIT implies handling of inventory in a much disciplined way. It requires changes in culture. It also encompasses the Japanese managerial characteristics i.e., Lifetime employment, implicit control mechanisms, collective decision making, collective responsibility and holistic concern for employees. JIT applies to all functions of a company not just the operations.
\end{abstract}

Keywords: Manufacturing; Ideal Resource; Sub - Assemblies; Inventory \& Optimal.

Cite This Article: Dr. C. Eugine Franco, and S.Rubha. (2017). "AN OVERVIEW ABOUT JIT (JUST-IN-TIME) - INVENTORY MANAGEMENT SYSTEM." International Journal of Research - Granthaalayah, 5(4)SE, 14-18. 10.29121/granthaalayah.v5.i4(SE).2017.1944.

\section{Introduction}

Just - In - Time inventory is generally regarded as an efficient inventory management system. Many suppliers and retailers partner in the early $21^{\text {st }}$ century to co-ordinate their Just - In -Time efforts. The JIT concept of production was introduced in Japan under the name of Kanban. It is generally associated with Japanese businessman Taichii Ohno. He introduced this production philosophy to meet the needs of the Japanese automobile market after World War II. Later JIT was adopted in United States, called as Learn Manufacturing. US companies seek to eliminate the wastes by calling it as Value Added manufacturing. It is a method that seeks to eliminate waste in processing Adhering to the edict that a stage of the process that does not add value to 
the product for the customer should be eliminated. By applying JIT many companies are improving their productivity.

\section{Meaning}

Just- in - Time is both a philosophy and set of methods for manufacturing. According to this concept material and components are supplied to the work station just at the time they are required for use.

\section{Purpose}

The purpose of JIT is to avoid waste associated with overproduction, waiting, excess inventory, total quality control and devotion to the customer. JIT inventory is intended to avoid situations in which inventory exceeds demand and places to manage the extra inventory. Manufactures using JIT processes want to use materials for production at levels that meet distributor or retailer demand but not in excess. Retailers only want to acquire and carry inventory that meets immediate customer demand as excess inventory requires storage and management cost. The list of seven wastes is the target for continuous improvement in production process. They are:

- Waste of overproduction: Eliminate by reducing setup times, synchronizing quantities and timing between processes, compacting layout, visibility, and so forth. Make only what is needed now.

- Waste of waiting: Eliminate through synchronizing work flow as much as possible, and balance uneven loads by flexible workers and equipment.

- Waste of transportation: Establish layouts to make transport and handling unnecessary if possible. Then rationalize transport and material handling that cannot be eliminated.

- Waste of processing itself: Extend thinking beyond economy of scale or speed, like why this part or product should be made at all, then why each process is necessary.

- Waste of stocks: Reduce by shortening setup times and reducing lead times, by synchronizing work flows and improving work skills, and even by smoothing fluctuations in demand for the product. Reducing all the other wastes reduces the waste of stocks.

- Waste of motion: Study motion for economy and consistency, economy improves productivity, and consistency improves quality.

- Waste of making defective products: Develop the production process to prevent defects from being made so as to eliminate inspection. At each process, accept no defects and make no defects.

\section{The Features of JIT are as follows:}

- There exist few reliable vendors that can deliver high quality inventory within very short time frames.

- Inventory is supplied in the nick of time in small lots which drastically reduces the carrying costs.

- Long term purchase contracts are entered into with suppliers at economical prices which curtail the paperwork and negotiation time associated with arriving at the supply price. 
- The inspection of inventory takes place as and when received, paving the way for a lean inventory management department.

- Transportation costs with regard to the movement of inventory from the storage locations to the production sites can be avoided.

- Goods are produced as per the requirement of the end-user and hence over-production and the resultant excess holding of inventory can be avoided.

- Payments are made for batches of goods supplied as per contract terms, rather than for small lots, which leads to effective working capital management.

- The production cycle becomes shorter, as the waiting time and interruptions due to delays are avoided.

- Wastage due to production of defective products is eliminated as the output at every stage of production is inspected, before passing on to the next stage.

\section{Advantages of Just- In-Time}

The use of just-in-time inventory has the following advantages:

- There should be minimal amounts of inventory obsolescence, since the high rate of inventory turnover keeps any items from remaining in stock and becoming obsolete.

- Since production runs are very short, it is easier to halt production of one product type and switch to a different product to meet changes in customer demand.

- The very low inventory levels mean that inventory holding costs (such as warehouse space) are minimized.

- The company is investing far less cash in its inventory, since less inventory is needed.

- Less inventory can be damaged within the company, since it is not held long enough for storage-related accidents to arise. Also, having less inventory gives materials handlers more room to manoeuvre, so they are less likely to run into any inventory and cause damage.

- Production mistakes can be spotted more quickly and corrected, which results in fewer products being produced that contain defects.

\section{Disadvantages Associated with Just-In-Time Inventory}

Despite the magnitude of the preceding advantages, there are also some disadvantages associated with just-in-time inventory, which are:

- A supplier that does not deliver goods to the company exactly on time and in the correct amounts could seriously impact the production process.

- A natural disaster could interfere with the flow of goods to the company from suppliers, which could halt production almost at once.

- An investment should be made in information technology to link the computer systems of the company and its suppliers, so that they can coordinate the delivery of parts and materials.

- A company may not be able to immediately meet the requirements of a massive and unexpected order, since it has few or no stocks of finished goods. 


\section{Examples Of JIT Users}

\section{TOYOTA}

Toyota is considered by many to be the poster child for JIT success. The Toyota production strategy is highlighted by the fact that raw materials are not brought to the production floor until an order is received and this product is ready to be built. No parts are allowed at a node unless they are required for the next node, or they are part of an assembly for the next node. This philosophy has allowed Toyota to keep a minimum amount of inventory which means lower costs. This also means that Toyota can adapt quickly to changes in demand without having to worry about disposing of expensive inventory.

Important Factors to Toyota Success: Small amounts of raw material inventory must be kept at each node in production, so that production can take place for any product. These parts are then replenished when they are used. Accuracy in forecasting-is important so the correct amount of raw materials can be stocked.

\section{DELL}

Dell has also leveraged JIT principle to make its manufacturing process a success. Dell's approach to JIT is different in that they leverage their suppliers to achieve the JIT goal. They are also unique in that Dell is able to provide exceptionally short lead times to their customers, by forcing their suppliers to carry inventory instead of carrying it themselves and then demanding (and receiving) short lead times on components so that products can be simply assembled by Dell quickly and then shipped to the customer.

\section{Important Factors to Dell's Success:}

- Dependable suppliers with the ability to meet Dell's demanding lead time requirements.

- A seamless system that allows Dell to transmit its component requirements so that they will arrive at Dell in time to fulfil its lead times.

- A willingness of suppliers to keep inventory on hand allowing Dell to be free of this responsibility.

\section{HARLEY DAVIDSON}

Harley Davidson's use of JIT is mostly characterized by its transformation in the late World War II era from an inefficient manufacturer that solved all of its problems with extra inventory to a nimble manufacturer able to meet demand and provide short lead times.

\section{Results of Harley Davidson's JIT Implementation:}

- Inventory levels decreased 75 percent.

- Increased productivity.

Harley Davidson's success with the implementation of JIT had a lot to do with the fact that when JIT was put into practice, process problems could no longer be hidden by costly inventory that helped to meet ship dates. The inefficiencies in the processes were quickly identified and solved. 


\section{Conclusion}

Just-In - Time is a manufacturing philosophy which leads to producing the required items, at the required quality and in the right quantities at the precise time as they are required. Just-In-Time manufacturing is a system of enforced problem solving. Managers have the choice between putting a huge effort in finding and solving causes of production problems, or they can learn to live with an intolerable level of interruptions in production. As everybody knows, the situation in which one has to put huge efforts is highly undesirable, and the system is called enforced. Quality within JIT manufacturing is necessary, because without a quality program in JIT, the JIT will fail. Therefore JIT implies on high quality at the Source and the Plan, Do, Check, Action with its statistical process control. Furthermore, techniques are also very important. The JIT technique is a pull system rather than a push system, based on not producing things until they are needed. The well-known Kanban card is used as a signal to produce. Moreover, integration also plays a key role in JIT systems. JIT has its influence in ordering, scheduling and producing sides of a manufacturing firm. This influence in manufacturing firm is depending on employees, suppliers or customers. Therefore a large element of training is put towards the JIT to reach certain goals. One of the important principles of JIT is mutual trust and team work. When the managers and workers find each other as equal, committed to the organisation and its success, they are more willing to co-operate with each other in order to find the problems and solve these problems. It is concluded that the implementation of JIT system, the positive outcomes that arise from the use of the system is far greater than those that are not. The JIT system really is a state of the art idea that is beginning to catch on in a tremendous way all over the world.

\section{References}

[1] Golden, S. A. R. (2011). A Study On Investment Pattern And Preference Of Investors In Trichy City, Tamil Nadu. RETELL, 12(1), 20-24.

[2] Golden, S. A. R. (2011). Strategy For Success Of Human Beings:-Time Management.

[3] Golden, S. A. R. (2014). A DESCRIPTIVE STUDY ON THE ROLE OF CONSUMER PSYCHOLOGY AND BEHAVIOUR IN PRODUCT PURCHASING'. Indian Streams Research Journal, 3(12), 1-6.

[4] Golden, S. A. R. (2014). A Study On Attitude Of Employee Towards Working Environment With Special Reference To RR Pvt Ltd.Review Of Research, 2(2), 1-5.

[5] Golden, S. A. R., \& Regi, S. B. (2015). Satisfaction of Customers towards User Friendly Technological Services offered by Public and Private Sector banks at Palayamkottai, Tirunelveli District. International Journal of Research, 2(3), 775-787.

[6] Regi, S. B., Golden, S. A. R., \& Franco, C. E. (2014). A STUDY ON IMPACT OF INFORMATION TECHNOLOGY (IT) IN MODERN BANKING SECTOR. Golden Research Thoughts, 3(9), 1-4.

[7] Regi, S. B., Golden, S. A. R., \& Franco, C. E. (2014). EMPLOYEE PERCEPTION TOWARDS EFFECTIVENESS OF HR PRACTICES IN PUBLIC SECTOR BANKS IN TIRUNELVELI DISTRICT. Tactful Management Research Journal, 2(6), 1-4.

[8] Regi, S. B., Golden, S. A. R., \& Franco, C. E. (2014). ROLE OF COMMERCIAL BANK IN THE GROWTH OF MICRO AND SMALL ENTERPRISES. Golden Research Thoughts, 3(7), 1-5.

[9] Snehalatha, C. S. V. CONSTRUCTING AND VALIDATING A SCALE FOR ASSESSING THE SOCIABILITY OF TEACHERS.

[10] https://en.wikipedia.org/wiki/just-in-time_manufacturing.

[11] www.businessdictionary .com/definition/just-in-time-JIT-inventory.html. 